\title{
Moderating Impact of Sustainable Building Awareness on the Relationship between Sustainability Concepts Application, Sustainability Constraints, and Knowledge Level
}

\author{
Nuruddeen Usman', Ilias Said ${ }^{2} \&$ Isyaku Mohammed $^{3}$ \\ ${ }^{1 \& 3}$ Department of Building Technology, Faculty of Environmental Technology, ATBU, Bauchi, Nigeria \\ ${ }^{2}$ School of Housing Building and Planning, University Sains Malaysia, 11800, Penang, Malaysia \\ *corresponding author: ilias@usm.my \\ Article History: Received:11 January 2021; Accepted: 27 February 2021; Published online: 5 April 2021
}

\begin{abstract}
Stakeholders do not adopt the concept of sustainable building in the building industry. Therefore, this research aimed at study the stakeholders' level of knowledge, awareness, and constraints of building sustainability concepts and how they affect the adoption of building sustainability concepts. A quantitative research design was employed using a questionnaire. A research sample of 201 was collected via a structured questionnaire survey that was randomly selected from 420 registered professionals in northwest Nigerian. Data collected were analysed using the SPSS and WarpPLS packages. The findings show that the level of knowledge and awareness was moderate among the stakeholders. Likewise, sustainability constraints have a negative effect on the adoption of building sustainability concepts, level of knowledge has a positive effect on the adoption of building sustainability concepts; awareness of sustainability concepts has improved the effectiveness of the relationship between sustainability constraints and adoption of building sustainability concepts, and awareness of sustainability concepts improves the effectiveness of the relationship between the level of knowledge and adoption of building sustainability concepts. Therefore, there is a need for the developing nations to emphasized regular sensitization of sustainability concepts and principles so that the menace of lack of its adoption can be curtailed.
\end{abstract}

Keywords: Sustainability, Building, Moderating, Awareness, Knowledge

\section{Introduction}

Resources (such as energy, water, raw materials, and the like) are used up in buildings; generated waste (occupant, construction, and demolition) appears; and potentially harmful atmospheric emissions appear to be emitted by buildings. Despite the significant challenge presented by building owners, designers, and builders, they have to respond to the relentless demands for new and renovated facilities that are accessible, secure, healthy, and productive, as well as being economical and having little to no impact on society, the environment, or the economy (Devies, 2017). Ernest et al. (2020) discovered that the aforementioned factors, in addition to economic, environmental, and social elements, have a major impact on construction materials pricing in developing countries. The idea is that building designs and construction should result in net positive benefits to all three building sections, as described in the Whole Building Design Guide (WBDG, 2014). Because the construction industry is the largest destroyer of the natural environment, they also consume the largest number of natural resources (Woolley, 2000). It is a serious consumer of non-renewable resources, generates significant waste, pollutes air and water, and contributes to land abandonment (Wallbaum \& Buerkin, 2003).

The possible development path that includes all of the concepts and measures necessary to achieve sustainable development and meets all of the requirements mentioned above but is sustainable over the long term (United Nations, 1987). In order to lessen the environmental or ecological impact on the planet, the main objective of sustainability is to cut back on humanity's environmental footprint. A rise in sustainable development has resulted in a rise in sustainable buildings. Building practises that are most effective to protect the environment fall into seven major categories: energy-saving, land-saving, stormwater runoff-reduction, material conservation, and pollution reduction (ECO Northwest, 2001).

In terms of energy consumption, an average sustainable building uses $30 \%$ less energy than a conventional building (Rao, 2001). This was the point in the design process at which a Modular Integrated Construction (MiC) was adopted because it has proven to contribute to decreased lifecycle costs, accelerated construction time, lower construction waste, better adaptability, reduced carbon emissions, and streamlining of the construction process (Wuni, Shen, \& Mahmud, 2019). Additionally, an enterprise risk management (ERM) model for analysis was proposed by Junying, Sui, and Qiang (2018) for ERM processes, ERM operations, and ERM control environments for construction industries, which are similar to what sustainability is advocating. As a result, the material waste created during construction is minimised or recycled. It may be advantageous to use sunlight, natural ventilation, or solar power in order to increase energy efficiency. Because less water is used, or a rainwater harvesting system is implemented, better usage of water is assured. Buildings in the natural environment (especially the architecture of these buildings) should be reduced to the greatest extent possible because they contribute to a multitude of 
environmental problems. Stakeholders (which include building owners, developers, architects, engineers, and contractors, as well as governments and non-profit organisations) have all promoted sustainable building design and construction to help mitigate this impact. Despite the pressures of the environment, the construction industry of Nigeria has a long history of practising unsustainable construction (Sani \& Abdulazeez, 2018). Shelter is required in addition to a variety of other necessities including staying protected from the elements and maintaining good health. The authors (Alsubeh, 2013) claimed that what is required is a dynamic equilibrium. The alternative is a production process that is friendly to the ecosystem and is therefore very competitive, with no danger whatsoever (Zubairu, 2012). When it comes to sustainable buildings, popularly referred to as environmentally friendly buildings, these requirements are satisfied.

\section{Sustainability in Construction}

Due to its effects on the environment, the construction industry must inevitably change the methods it has historically used with no regard for the impact. Instead, the industry will focus on replacing the older method of operating with a replacement model that aims to bring up environmental concerns as a central pillar of its efforts. While environmental concerns were previously just a small component of construction projects, these concerns have increased in prominence. While greater attention has been given to the environmental impact of construction due to depletion of non-renewable resources, the increase in global warming, and the severe destruction of the environment and biodiversity, the impact of this problem has spread worldwide. A lot of effort is being put forth to the cause of sustainability in the construction industry. This has promoted the evolution of an improved approach to health and safety regulations in construction in Nigeria (Nnedinma, Konstantinos, \& Abimbola, 2020), which is one of the foundational aspects of sustainability. The industry is now shifting away from developing products with an environmental footprint as a small part of the process and is instead implementing an event-driven approach that includes environmental objectives in all facets of the process. Thus, construction companies must not only comply with environmental needs, but also must work and develop in order to sustain and protect the environment (2005).

Green construction, also known as sustainable construction, is known as a responsible way of ensuring the wellbeing of a community, in this case a city. Sustainability has come to be seen as a cure-all for social and economic change and development (Hayles, 2004). Sustainable construction could be defined as a procedure through which, over time, sustainability is accomplished. It is necessary to bring the concept of sustainability to bear on the development industry to influence how a project should be carried out in order to strike a balance between preserving the environment and fostering economic growth. What it really means to be sustainable is to have a particular level of negative impact (which, obviously, is impossible) and not going overboard (2000). As of early in the history of sustainability in construction, the discussion was mainly focused on limited resources like energy, and the manner in with which one could reduce the impact on the natural environment. The overall strategy was to optimise technical issues like building components, construction technologies, and energy-related design concepts. Because people value and recognise the importance of non-technical issues (soft issues), the appreciation of economic and social sustainability concerns has also grown. Because of this, appreciation of the importance of the built environment's cultural heritage has also increased. Environmental protection, social wellbeing, and economic prosperity are some of the three main pillars on which the concept of sustainable construction currently relies (2014). 


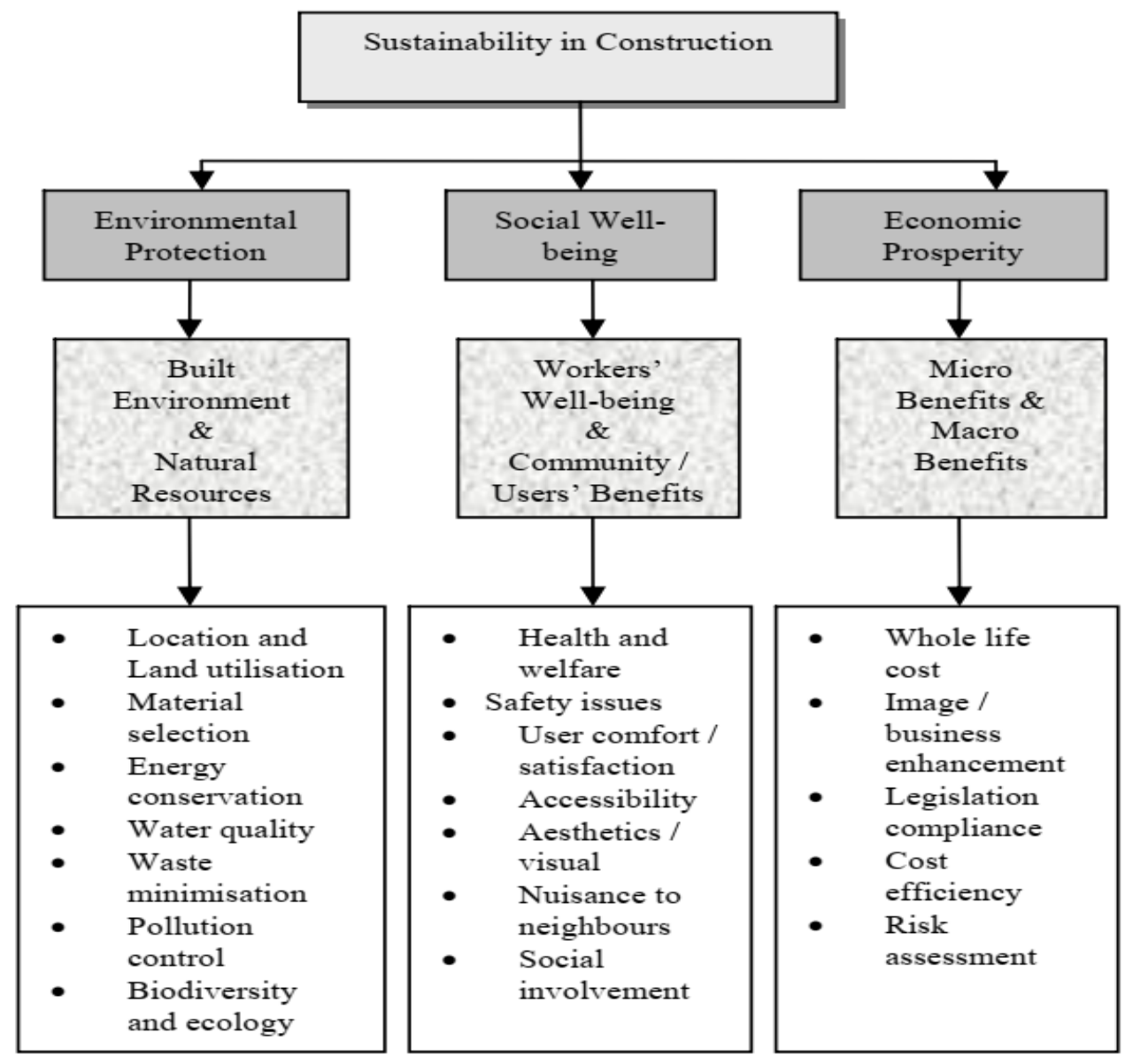

Figure 1: Sustainability in Construction (Zainul Abidin, 2005)

In the example shown here, Figure 1 illustrates the tree diagram of these three headings and their areas of concern. Environmental protection is most concerned with the built environment and the natural environment. The built environment, also known as the development project, refers to the activities within the project itself. If those activities are not managed well, the environment will be negatively impacted. As well as the recovery of natural resources, environmental sustainability is concerned with sustainability of natural resources. Though builders have little influence on the extraction of natural resources, they will help discourage the extraction of natural resources by demanding less non-renewable natural resources, more recycled materials, and more efficient use of energy and mineral resources (Addis \& Talbot, 2001). A theory about social well-being that encompasses workers' well-being and future users' well-being. This feature is concerned with people's feelings such as security, happiness, safety, and luxury. In addition, it takes into consideration human contributions such as skills, health, knowledge, and motivation (Parkin, 2000). Finally, it is also an issue of economic sustainability, which focuses on both micro- and macro-economic benefits. Micro-economics deals with the various factors or activities that may result in monetary gains from the project's development, while macro-economic focuses on the economic advantages that the project offers to the general public and the government.

\section{Sustainable Building}

A sustainable building is a building that was designed and constructed using sustainable methods and materials that doesn't harm the environment or the health and well-being of the building's occupants, construction workers, the general public, or future generations. To achieve a sustainable building, a variety of considerations must be taken into account, including land use, environmental impacts, indoor air quality, energy and water use, lifecycle impacts of building materials, and solid waste. Green building is often defined as the practise of sustainable construction, which includes the creation and responsible management of a healthy built environment that supports the prudent use of resources and ecological principles (Kilbert, 1994). It's safe to say that Abdulwahed, Farzad, Mostafa, and Saeed (2019) are correct in claiming that an array of sustainable building materials makes it difficult for the adoption of sustainable products. In their article, Reddy, Kumar, Raj, (2019) made the claim that a material selection exercise is a critical aspect of achieving sustainability. 
A sustainable construction ethic calls for a cradle to grave evaluation of the project, which involves managing the long-term serviceability of the project and eventual deconstruction' (Wyatt,1994). Sustainable construction may be defined as the creation and responsible management of a healthy built environment based on the prudent use of resources and ecological principles (Kilbert, 1994). An increase in the percentage of sustainable construction contractors will be necessary if the existing contract bidding model is not to encourage the use of sustainable construction practises. To start, only construction firms with efficient resource capabilities may take sustainability into consideration when planning and implementing projects (Bamgbade et. al. 2019). In order to create a longterm, sustainable project, it is important to meet set-down principles. Without considering constraints that limit the adoption of sustainability concepts, it is essential to study stakeholders' level of knowledge and awareness of building sustainability concepts in order to identify whether sensitization can mitigate the effect that application/adoption of sustainability concepts in developing nations has on stakeholders. Therefore, the research hypotheses are:

$\mathrm{H} 1=\quad$ Sustainability constraints have a significant positive effect on the adoption of building sustainability principles.

$\mathrm{H} 2=\quad$ Level of knowledge has a significant positive effect on the adoption of building sustainability principles.

$\mathrm{H} 3=\quad$ The awareness of sustainability principles will significantly improve the effectiveness of the relationship between sustainability constraints and the adoption of building sustainability principles.

$\mathrm{H} 4=\quad$ The awareness of sustainability principles will significantly improve the effectiveness of the relationship between the level of knowledge and adoption of building sustainability principles.

\section{Research Methodology}

This research is based on a deductive research methodology that utilises a quantitative research approach for the systematic empirical investigation of a social phenomenon through quantitative techniques. These individuals are primarily all professionals in the construction industry, but contractors, developers, and clients are also included. The results were found through the use of a well-formulated questionnaire. This study uses the total number of professionals in the north-west, Nigeria as the sample frame. Based on the Krejcie and Morgan (1970) table, the total population $(\mathrm{N})$ was 420 , and the sample size using that table was found to be $\mathrm{S}=201$. As randomness that is associated with generalizability, which also implies that the degree to which the sample represents the population influences the degree to which the study's results can be generalised to the entire population of the study, probability sampling was used to select the respondents. The data were analysed using SPSS (a statistical software package for social sciences), WarpPLS (a computational package for mathematical modelling), and shown in figures and tables. The scale was composed of five Likert-type response options, and each option corresponded to one variable. Cronbach's alpha is a measurement of internal consistency. This metric is limited to 0 and 1 , with a degree of reliability approaching 1 showing a high level of reliability on the items in the research instrument.

\section{Results}

\section{Presentation of Data from Questionnaire Survey}

Data were collected through a questionnaire survey and is presented thus:

Table 1: Questionnaire distribution

\begin{tabular}{lll}
\hline Questionnaires & No & \% \\
\hline Distributed & 201 & 100 \\
Retrieved and valid & 193 & 96.02 \\
Non-retrieved & 8 & 3.98 \\
\hline
\end{tabular}

(Source: Fieldwork, 2019)

A total of 201questionnaires were distributed, of which 193 were retrieved for further analysis, as shown in Table 1 .

Table 2: Level of Knowledge Regarding Sustainability Concepts and Sustainable Building

\begin{tabular}{lc}
\hline Question Items & Mean \\
\hline Location and Land utilization & 2.76 \\
Material selection & 3.20 \\
Energy conservation & 2.23 \\
Water quality & 2.74 \\
\hline
\end{tabular}


Moderating Impact of Sustainable Building Awareness on the Relationship between Sustainability Concepts Application, Sustainability Constraints, and Knowledge Level

\begin{tabular}{ll}
\hline Waste minimization & 2.50 \\
pollution control & 2.44 \\
Biodiversity and ecology & 2.53 \\
Health and welfare & 2.67 \\
Safety issues & 3.20 \\
User comfort/satisfaction & 2.94 \\
Aesthetic/visual view & 3.17 \\
Nuisance to neighbors & 3.08 \\
Social involvement & 3.19 \\
Whole life costing & 2.78 \\
Image/business enhancement & 2.76 \\
Legislation compliance & 2.97 \\
Cost Efficiency & 2.94 \\
Risk Assessment & 2.76 \\
\end{tabular}

Table 2 shows the assessment of respondents level of knowledge regarding sustainability concepts, eighteen items regarding sustainability concepts were presented, respondents level of knowledge with the highest mean score (MS) was material selection and safety issues respectively 3.20 above average (AA), followed by social involvement with (MS) of 3.19 (AA), aesthetics/visual view with (MS) of 3.17 (AA), reduction of nuisance to neighbour (MS) value was 3.08 (AA) followed by legislation compliance having (MS) of 2.97 average (A), respondent knowledge on whole life costing (MS) 2.78 (A), risk assessment and location and land utilization with (MS) values of $2.76(\mathrm{~A})$, respondent knowledge on water quality (MS) is $2.74(\mathrm{~A})$, then health and welfare (MS) 2.67 (A) followed by biodiversity and ecology 2.53 (A), lastly with the lowest (MS) values was waste minimization, pollution control and energy conservation having (MS) values of 2.50 (A), 2.44 below average (BA) and 2.23 (BA) respectively. This inferred that respondent level of knowledge on the protection of the environment was average (A) with a score value of (2.63), regarding attainment of social well-being was above average (AA) with a score value of (3.04) and that of achieving economic prosperity was average(A) having a value of (2.84).

Therefore, respondents' general knowledge of sustainability concepts was average, with a score value of (2.84). Meaning that the majority of respondents had moderate knowledge regarding sustainability concepts and sustainable building.

Table 3: Level of awareness about the concept of sustainable building

\begin{tabular}{lc}
\hline Question Items & Mean \\
\hline Protection of the environment & 2.79 \\
Prudent use of natural resources & 2.67 \\
Social progress for everyone & 2.91 \\
Maintaining economic growth & 2.83 \\
Quality of life and consumer satisfaction & 2.92 \\
Environmental planning, management, and control & 2.73 \\
Generating profit without compromising future needs & 2.55 \\
\hline
\end{tabular}

In Table 3, it can be seen that, with regard to sustainable building, the respondent was aware of seven items, with responses ranging from slightly knowledgeable to very knowledgeable. The MS produced a value of 2.92 (quality of life), which had the highest consumer satisfaction recorded, followed by 2.91 (social progress for everyone), which had the highest value of social progress for everyone, which had the second highest value of social progress for everyone, which was followed by maintaining economic growth (with a mean value of 2.83 (A)) and keeping natural resources safe (with a mean value of 2.73 (A)). Social progress for everyone had the highest value of social progress for everyone, which was followed by the protection of the environment, environmental planning and control, prudent use of natural resources, and generating profit while also preserving future needs (with a mean value of $2.79(\mathrm{~A}), 2.73(\mathrm{~A}), 2.67(\mathrm{~A})$, and $2.55(\mathrm{~A})$.

This implies that the respondent level of awareness of sustainable building is moderate having mean scores values of (2.77) on a 5-point Likert scale. 
Table 4: Constraint Hindering the Application of Sustainable Building

\begin{tabular}{|c|c|c|}
\hline Constraints & Mean & Ranking \\
\hline Lack of training on sustainable building & 3.86 & 1 \\
\hline Lack of government incentive and support & 3.7 & 2 \\
\hline Difficulty in the procurement of sustainable building product or component & 3.68 & 3 \\
\hline Lack of articulated demand by the client & 3.58 & 4 \\
\hline Lack of enforcement & 3.58 & 4 \\
\hline Higher final cost or perceived cost & 3.55 & 5 \\
\hline Extensive pre-contract planning & 3.55 & 5 \\
\hline Lack of database and information & 3.53 & 6 \\
\hline Lack of time available to identify and evaluate alternatives & 3.53 & 6 \\
\hline Higher investment cost & 3.46 & 7 \\
\hline Lack of public awareness of sustainable building & 3.46 & 7 \\
\hline Uncertainty on project completion time & 3.44 & 8 \\
\hline Change resistance & 3.43 & 9 \\
\hline Risk of investment & 3.38 & 10 \\
\hline Uncertainty about the quality of sustainable building construction & 3.37 & 11 \\
\hline Inappropriate regulation & 3.34 & 12 \\
\hline Lack of cooperation and interaction among professionals/stakeholders & 3.3 & 13 \\
\hline Lack of interest from the design and construction team & 3.22 & 14 \\
\hline Lack of strategies to promote sustainable building & 3.13 & 15 \\
\hline Lack of expertise & 3.09 & 16 \\
\hline The gap between designer and end-users & 3.04 & 17 \\
\hline $\begin{array}{l}\text { Lack of access to consistent, comparable information about sustainable } \\
\text { building materials }\end{array}$ & 3 & 18 \\
\hline $\begin{array}{l}\text { Higher logistics cost involved in importing sustainable building product or } \\
\text { component }\end{array}$ & 2.98 & 19 \\
\hline Lack of building codes and regulation & 2.9 & 20 \\
\hline $\begin{array}{l}\text { Client/Developer sees sustainable building construction will belittle their } \\
\text { social status }\end{array}$ & 2.87 & 21 \\
\hline Sustainable building product not available in Nigeria & 2.75 & 22 \\
\hline The shortcoming in the existing structure of the construction industry & 2.68 & 23 \\
\hline $\begin{array}{l}\text { Lack of information about sustainable building materials often incomplete } \\
\text { or difficult to interpret }\end{array}$ & 2.66 & 24 \\
\hline Not sure where to obtain information on sustainable building & 2.40 & 25 \\
\hline
\end{tabular}

Table 4 indicates the major constraints hindering the acceptability of sustainable building practices in Nigeria. Lack of training on sustainable buildings was ranked 1 with the highest (MS) value of 3.86, followed by lack of government incentives, support then the difficulty in the procurement of sustainable products or components, lack of articulated demand by the client and lack of enforcement with their mean score values of 3.72, 3.68 and 3.56 , respectively. Hence, we take two, three, and four rankings.

The constraint with a mean score value above 3.50, is considered as a major factor, which inferred that the higher the mean score value, the higher the factor hindering the acceptability to practice sustainable building concepts. 
From the foregoing, this implies that most of the respondents were not trained/informed about sustainable building construction and the government not providing the necessary incentives and support to enhance the practice of sustainable building construction in Nigeria. There are difficulties in the procurement of sustainable building products/components. Government agencies are not doing enough to enforce laws for the achievement of environmental protection, social progress, and attainment of economic prosperity.

\section{Direct Effect}

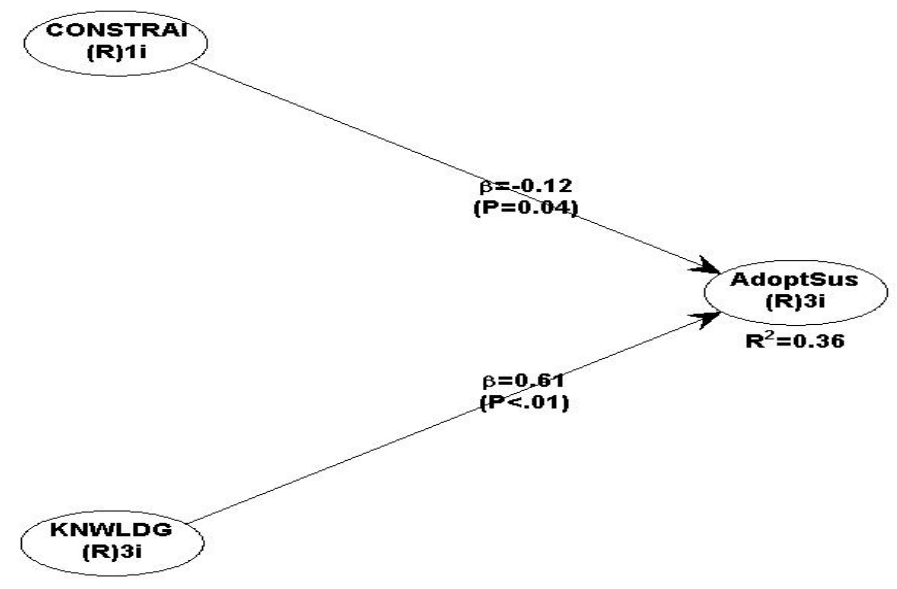

Figure 3: Model of the relationship between sustainability constraints, level of knowledge, and adoption of sustainability concepts.

Figure 3 presents the direct effect model of sustainable building constraints on the adoption of sustainable building regulations, which shows a beta value of -0.12 , with a P-value of 0.04 , which means that as the sustainability constraints increase, it can significantly decrease the application of sustainability concepts. It also shows that as the level of knowledge increases, it may significantly increase the application of sustainable building concepts by a beta value of 0.61 , with a P-value of less than 0.01 .

The Model fit and quality indices have an APC value of 0.363 at P-value less than 0.001 , which is acceptable because it is less than 0.05 , ARS and AARS values are 0.241 and 0.235 , with P values of less than 0.001 , which is acceptable because ARS and AARS are greater than 0.2 and P values less than 0.05 .

Table 5: Latent variables' direct effect coefficients

\begin{tabular}{|l|c|c|c|}
\hline & $\begin{array}{c}\text { Sustainability } \\
\text { constraints }\end{array}$ & $\begin{array}{c}\text { Level of } \\
\text { knowledge }\end{array}$ & $\begin{array}{c}\text { Adoption of } \\
\text { sustainability }\end{array}$ \\
\hline $\mathrm{R}^{2}$ & & & 0.357 \\
\hline Adj. $\mathrm{R}^{2}$ & 1.000 & 0.872 & 0.350 \\
\hline $\mathrm{Q}^{2}$ & 1.000 & 0.779 & 0.440 \\
\hline $\begin{array}{l}\text { Composite } \\
\text { Reliability }\end{array}$ & & & 0.958 \\
\hline $\begin{array}{l}\text { Cronbach's } \\
\text { alpha }\end{array}$ & & & \\
\hline
\end{tabular}

Validation performed on the dependent variable in Table 5 shows the values obtained for $\mathrm{R}^{2}$ coefficient $=0.357$, adjusted $R^{2}$ coefficient $=0.350$ and $Q^{2}$ coefficient $=0.440$, which are all above 0.2 , showed acceptable values. In addition, the composite reliability and Cronbach alpha of all the latent variables are above 0.70, it is concluded that all the latent variables had sufficient internal validity. 


\section{Moderating Effect}

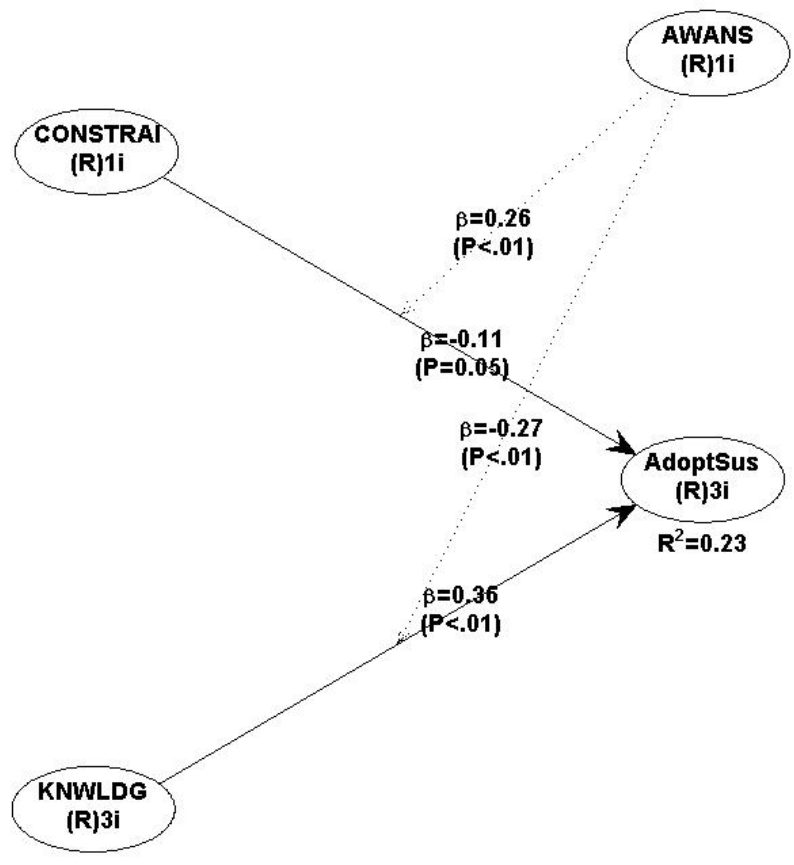

Figure 4: Model showing the moderating effect of awareness on the relationship between sustainability constraints, level of knowledge, and adoption of sustainability concepts.

The moderating effect model presented in Figure 4 shows the impact of awareness, which is the moderator of the independent variables (sustainability constraints and level of knowledge) effect on the adoption of sustainable building concepts (dependent variables). The impact of awareness on the effect of sustainability constraints on the sustainable building concepts link shows that if there is an increase in awareness along with sustainability constraints link, there will be a significant increase in the adoption of sustainability concepts with a beta value of 0.26 , at a P-value of less than 0.01 , equally, it decreases the effect of sustainability constraints on the adoption of sustainability building concepts with a beta value of -0.11 , at a moderate P-value of 0.05 .

Furthermore, the moderating impact of awareness along with the knowledge level link shows that awareness decreases the effect of the level of knowledge on the application of sustainable building concepts with a beta value of -0.27 at a P-value of less than 0.01. However, it significantly increases the application of sustainable building concepts by a beta value of 0.36 , with a P-value of less than 0.01 , along with the level of knowledge link. However, the moderating impact of awareness affects the strength of the beta coefficient, which decreases from 0.61 0.36.

In addition, the model fit, and quality indices have an APC value of 0.251 at P-value less $<0.001$, which is acceptable because it is less than 0.05, ARS and AARS values of 0.231 and 0.215 , with $P$ values of 0.001 , which is acceptable because ARS and AARS are greater than 0.2 and P values less than 0.05 .

Table 6: Latent variables' moderating effects coefficients

\begin{tabular}{|l|c|c|c|c|c|c|}
\hline & $\begin{array}{c}\text { Sustainabil } \\
\text { ity } \\
\text { constraints }\end{array}$ & $\begin{array}{c}\text { Level of } \\
\text { knowled } \\
\text { ge }\end{array}$ & $\begin{array}{c}\text { Awarene } \\
\text { ss }\end{array}$ & $\begin{array}{c}\text { Adoption of } \\
\text { sustainability }\end{array}$ & $\begin{array}{c}\text { Awareness } \\
\text { vs } \\
\text { Sustainabilit } \\
\text { y constraints }\end{array}$ & $\begin{array}{c}\text { Awarene } \\
\text { ss vs } \\
\text { level of } \\
\text { knowled } \\
\text { ge }\end{array}$ \\
\hline $\mathrm{R}^{2}$ & & & & 0.231 & & \\
\hline Adj. $\mathrm{R}^{2}$ & & & & 0.215 & & \\
\hline $\mathrm{Q}^{2}$ & 1.000 & 0.872 & 1.000 & 0.569 & & \\
\hline $\begin{array}{l}\text { Composite } \\
\text { Reliability }\end{array}$ & 1.000 & 0.779 & 1.000 & 0.934 & 1.000 & 0.896 \\
\hline $\begin{array}{l}\text { Cronbach's } \\
\text { alpha }\end{array}$ & & & & & & \\
\hline
\end{tabular}


Moderating Impact of Sustainable Building Awareness on the Relationship between Sustainability Concepts Application, Sustainability Constraints, and Knowledge Level

Validation performed on the dependent variable in Table 6 shows the values obtained for $\mathrm{R}^{2}$ coefficient $=0.231$, adjusted $\mathrm{R}^{2}$ coefficient $=0.215$ and $\mathrm{Q}^{2}$ coefficient $=0.569$, which are all above 0.2 , showed acceptable values. In addition, the composite reliability and Cronbach alpha of all the latent variables are above 0.70, it is concluded that all the latent variables had sufficient internal validity.
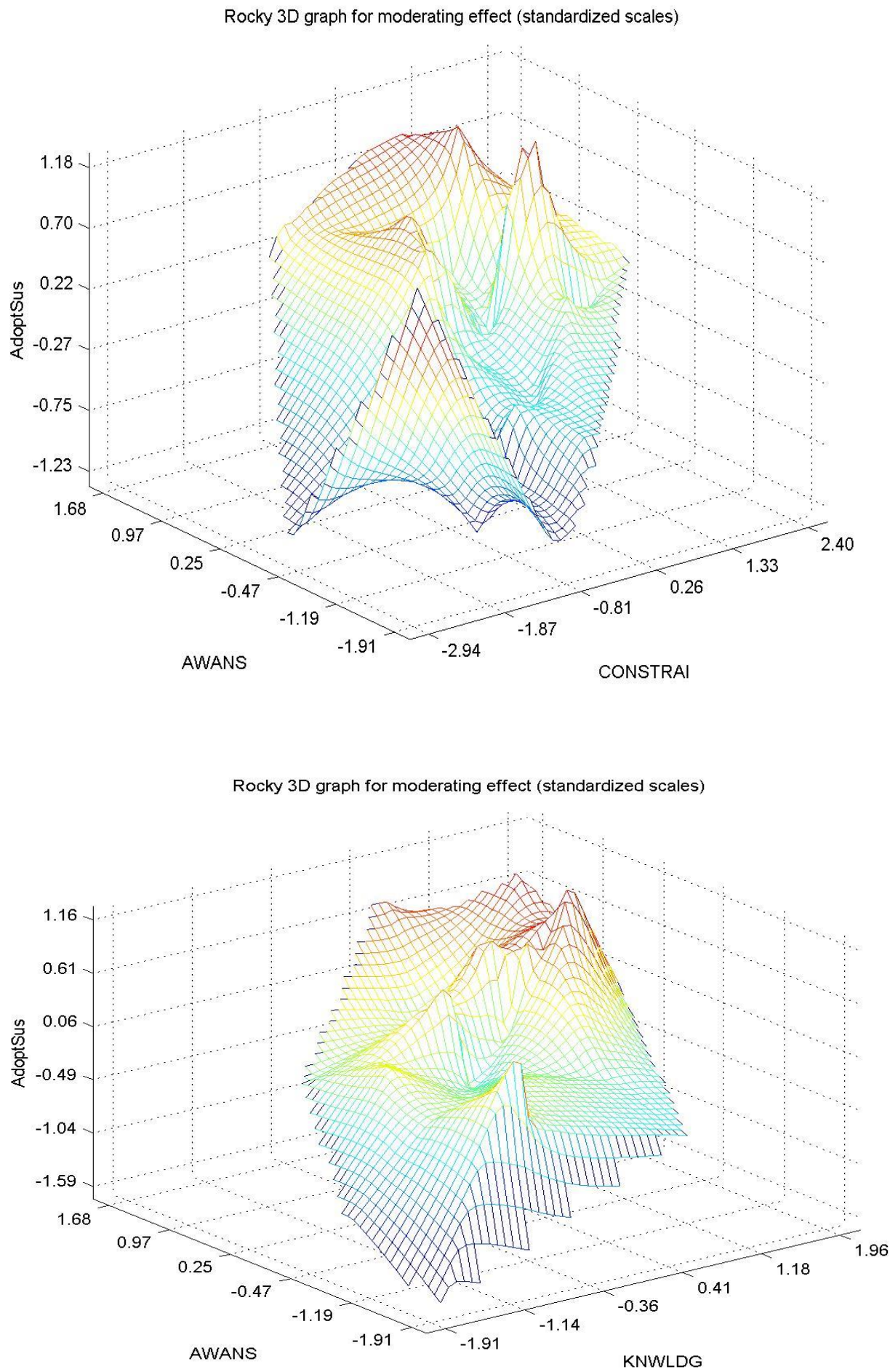

Fig. 5a, \& 5b: Rocky 3D graph for moderating effect

A graph representing the moderating effect is illustrated in Figures $5 \mathrm{a}$ and $5 \mathrm{~b}$ by using a 3D graph, with the data on the $\mathrm{X}$-axis and the sign and strength of the path coefficient of a moderating relationship on the $\mathrm{Y}$-axis. The signs in the direct relationship path point from negative to positive with respect to sustainability constraints, levels 
of knowledge, and awareness of sustainable building concepts. The signs are in favour of a positive direct relationship to sustainability constraints, levels of knowledge, and awareness of sustainable building concepts (awareness). Also, the sign of the path coefficient for the corresponding moderating relationship is positive, and the path coefficient is sufficiently high to yield a significant effect of awareness on the adoption of sustainable building concepts.

\section{Discussion}

From the finding of these research work respondent's general knowledge/awareness on sustainability concepts and sustainable building has an average mean value of 2.84 and 2.77 respectively. Meaning that the majority of the respondents have moderate knowledge and awareness regarding sustainability concepts and sustainable building, this is similar to the findings reported by Umar and Khamidi (2012), Yong et al. (2014), and Sani and Abdulazeez (2018), it implies that there is a brighter prospect in the application of sustainable building in developing nations, especially Nigeria. Again, the direct effect along the line of relationship between sustainability constraints and application of sustainability concepts shows, as there is a significant increase in the number of constraints; consequently, it may cause a decrease in the adoption of sustainability concepts in buildings, which might affect the prospect of developing nations in the adoption of the world bank principles of sustainable innovations. On the other hand, along with the knowledge level and adoption line of relationship shows, as the level of knowledge increases, it can subsequently increase the adoption of building sustainability principles. Following this, a moderating variable Awareness was introduced to assess its' impact along with the sustainability constraints and knowledge level link to the adoption of sustainability principles to find out whether it can improve its' adoption. Therefore, the impact of the findings along with constraints link implies that as there is an increase in awareness against the constraints, it will consequently significantly increase the application of sustainability concepts. Likewise, along with the level of knowledge link, as the level of knowledge increases, it can significantly increase the adoption of sustainability concepts in developing nations. This finding concurred with what Sodangi (2019) found in his study in the middle East region, where stakeholders' sustainability concepts on civil engineering practices in the construction industry were improved by awareness.

Table 7: Summary of Findings

\begin{tabular}{|l|l|l|l|l|l|l|}
\hline Hypothesis & \multicolumn{1}{|c|}{ DV } & \multicolumn{1}{|c|}{ IV } & MV & Beta value & P-value & Conclusion \\
\hline $\mathrm{H}_{1}$ & $\begin{array}{l}\text { Adoption of } \\
\text { Sustainability }\end{array}$ & $\begin{array}{l}\text { Sustainability } \\
\text { Constraints }\end{array}$ & & -0.12 & 0.04 & Not accepted \\
\hline $\mathrm{H}_{2}$ & $\begin{array}{l}\text { Adoption of } \\
\text { Sustainability }\end{array}$ & $\begin{array}{l}\text { Level } \\
\text { Knowledge }\end{array}$ & & 0.61 & $<0.01$ & Accepted \\
\hline $\mathrm{H}_{3}$ & $\begin{array}{l}\text { Adoption of } \\
\text { Sustainability }\end{array}$ & $\begin{array}{l}\text { Sustainability } \\
\text { Constraints }\end{array}$ & $\begin{array}{l}\text { Awareness of } \\
\text { Sustainability } \\
\text { concepts }\end{array}$ & -0.11 & 0.05 & Accepted \\
\hline $\mathrm{H}_{4}$ & $\begin{array}{l}\text { Adoption } \\
\text { Sustainability }\end{array}$ & $\begin{array}{l}\text { Level } \\
\text { Knowledge of }\end{array}$ & $\begin{array}{l}\text { Awareness of } \\
\text { Sustainability } \\
\text { concepts }\end{array}$ & 0.36 & $<0.01$ & Accepted \\
\hline
\end{tabular}

\section{Conclusion}

Conclusively, this research found that the level of knowledge and awareness of the concept of sustainability and sustainable building was moderate in developing nations such as Nigeria. About the effect of sustainability constraints and knowledge level on the adoption of sustainability concepts, the study found that the impact of sustainability constraints on the adoption of sustainability concepts leads to a significant decrease in the adoption/application of the sustainable building concepts. On the other hand, an increase in knowledge level leads to a significant increase in the adoption of sustainability concepts.

Furthermore, a moderating variable (awareness) was introduced to check whether it could improve the acceptability of sustainability concepts. awareness improves the adoption of sustainability concepts along both lines of relationship with sustainability constraints and knowledge levels. Finally, based on the findings, it is 
Moderating Impact of Sustainable Building Awareness on the Relationship between Sustainability Concepts Application, Sustainability Constraints, and Knowledge Level

recommended that developing countries emphasize sensitization on the importance of sustainability concepts and principles.

\section{References}

1. Abubakar S. H (2010) Research Methods; A Simple Guide to Educational Inquiry. Kano: SK.Amadu Printing Abdulwahed Fazeli, Farzad Jalaei, Mostafa Khanzadi \& Saeed Banihashemi (2019) BIMintegrated TOPSIS-Fuzzy framework to optimize selection of sustainable building components, International Journal of Construction Management, DOI: $10.1080 / 15623599.2019 .1686836$

2. Addis B. and R. Talbot, (2001) Sustainable Construction Procurement: A Guide to Delivering Environmentally Responsible Projects, CIRIA C571, London: CIRIA, Alsubeh, M.A. (2013) 'A strategic framework for sustainable construction in Jordan', Civil and environmental Research, 3(2),102-107.

3. American Society of Civil Engineers ASCE, (2008).Committee on sustainability. Report of Forum on Technical Opportunities for Sustainable Infrastructure, Reston VA: American Society of Civil Engineers.

4. American Society of Civil Engineers ASCE. (2005). the role of the Civil Engineer in unsustainable Development. Reston VA: American Society of Civil Engineers Ann Arbor MI: National Institute of Standards and Technology.

5. Bamgbade J. A., Nawi M. N. M., Kamaruddeen A. M., Adeleke A. Q. \& Maruf Gbadebo Salimon (2019) Building sustainability in the construction industry through firm capabilities, technology and business innovativeness: empirical evidence from Malaysia, International Journal of Construction Management, DOI: 10.1080/15623599.2019.1634666

6. Davies, D. R. (Ed.).(2005) Green Value: Green Buildings, Growing Assets, London, United Kingdom: Royal Institution of Chartered Surveyors.

7. Davies O.O.A, \& Davies I.O.E (2017) Barriers to Implementation of Sustainable Construction Techniques MAYFEB Journal of Environmental Science, 1-9 ECONorthwest (2001).Green Building: Saving Money and the Environment; Opportunities For Louisiana. Eugene, Oregon:

8. El-Sayegh M. Sameh, Tarek AbdRaboh, Dania Elian, Nahed ElJarad \& Yousef Ahmad (2020) Developing a bi-parameter bidding model integrating price and sustainable construction practices, International Journal of Construction Management, DOI: 10.1080/15623599.2020.1768625

9. Ernest Kissi, Asare Senyah Samuel, Daniel Yamoah Agyemang, Oteng Daniel \& Debrah Caleb (2020) Identification of factors influencing the pricing of sustainable construction materials in developing countries: views of Ghanaian quantity surveyors, International Journal of Construction Management, DOI: $10.1080 / 15623599.2020 .1768462$

10. Gottfried, D. A. (1996) Sustainable Building Technical Manual.US Department of Energy, US Green Building Council, and US Environmental Protection Agency, Urban Consortium Environmental and Energy Task Forces. Public Technology, Inc.

11. Heerwagen, J. (2000) "Green Building, Organisational Success and Occupant Productivity", Building Research and Information, 28, 5/6, $353-367$, Hayles C. (2004). "The Role of Value Management in the Construction of Sustainable Communities", The Value Manager [Online], Vol. 10, no.1,Available:http://www.hkivm.com.hk/publications/04/TVM2004-1.pdf

12. Junying Liu, Sui Pheng Low \& Qiang Zhang (2018) Enterprise risk management practices of top ENR international contractors, International Journal of Construction Management, 18:5, 364374, DOI: $10.1080 / 15623599.2017 .1326299$

13. Kats, G., \& Capital, E. (2003). The cost and financial benefits of green buildings: A report to California's sustainable building task force developed for the Sustainable Building Task Force. California, USA.

14. Kilbert, C. J. (1994).Principles of Sustainable Construction. Proceedings of the First International Conference on Sustainable Construction, 6-9 November, Tampa, Florida, USA, Page 1-9.

15. Koga, J. E., \& Lehman, T. (2008).The Value of Sustainability.Dayton OH: SAVE International

16. Krejcie, R.V. and Morgan, D.W. (1970), "Determining sample size for research activities", Educational and Psychological Measurement, Vol. 30 No. 3, pp. 607- 610.

17. Leadership in Energy and Environmental Design LEED (2008) Cost Study.US General Services Administration, Office of the Chief Architect. Washington DC: US General Services Administration Lockwod, C. (2006) Building the Green Way. Harvard Business Review 130. 
18. Lombardi, P.L (2001) "Responsibilities Towards the Coming Generations: Forming a New Creed", Urban Design Studies, vol. 7, 89 - 102, Means R.S. Company(2002) Green Building: Project Planning and Estimating(2nd Editioned.). Kingston, MA: Reed Elsevier Group PLC

19. Miyatake, Y. (1996). Technology Development and Sustainable Construction .Journal of Management Engineering, 12(4), 23-27. http://dx.doi.org/10.1061/(ASCE)0742597X(1996)12:4(23)

20. Ministry of Works, Housing and Transportation MWHT, (2016). Registered Contractors and Developers; Register, Kano Nigerian Institute Architect Kano State Chapter Office NIA, (2017).Professional member Register Nigerian Institute of Quantity Surveyors NIQS, (2017). Kano State Chapter Office: Professional member Register (Nigerian Institute of Quantity Surveyors) Kano, Nigeria Nigerian Society of Engineers NSE, (2017).Kano State Chapter Office: Financial member Register (Nigerian Society of Engineers) Kano, Nigeria

21. Nnedinma Umeokafor, Konstantinos Evangelinos \& Abimbola Windapo (2020) Strategies for improving complex construction health and safety regulatory environments, International Journal of Construction Management, DOI: $\underline{10.1080 / 15623599.2019 .1707853}$

22. Nor, M. A. (2009).Statistical methods in Research. Published by Prentice Hall. Pearson Malaysia Sdn Bhd.

23. Ofori, G C. Briffett, G. Gang and M. Ranasinghe, (2000) "Impact of ISO 14000 on Construction Enterprises in Singapore," Construction Management and Economics, vol. 18, pp. 935 - 947, Parkin, S. (2000) "Sustainable Development: the concept and the practical challenge", Proceedings of the Institution of Civil Engineers: Civil Engineering, 138(special issue 2), $3-8$,

24. Rao, S., \& Brownhill, D. (2001). European green building forum 2 - green file. EU: Brussels Rawlinson, S. (2007) Sustainability Offices. Building Magazine: 55

25. Reddy A. Suchith, Kumar P. Rathish \& Raj P. Anand (2019) Entropy-based fuzzy TOPSIS framework for selection of a sustainable building material, International Journal of Construction Management, DOI: $\underline{10.1080 / 15623599.2019 .1683695}$

26. Sani, K. I., \&Abdulazeez, U. R., (2018). Green building public awareness for client's benefits realization in Kano, Nigerian. International academic conference, Venice. 71(7), 113-123. http://:10.20472/IAC.2018.041.020

27. Schendler, A. (2002) Where's the Green in Green Business? Harvard Business Review Scheuer, C. W., and G.A. Keoleian, (2002) Evaluation of LEED Using Life Cycle Assessment Methods. The University of Michigan, Center for Sustainable Systems.

28. Sodangi Mahmoud (2019) Overcoming the constraints to the adoption of sustainable civil engineering practices, International Journal of Construction Management, DOI: 10.1080/15623599.2019.1569815

29. Umar, UA and Khamidi, M.F. (2012) 'Determined the level of green building public awareness: application and strategies, International Conference on Civil, Offshore and Environmental Engineering, pp.1-6, Kuala Lumpur, Malaysia.

30. United Nations, (1987). Report of the World Commission on Environment and Development. General Assembly Resolution 42/187.

31. United States Green Building Council USGBC.(2009). Green buildings by the numbers. http://www.usgbc.org/ShowFile.aspx ?Document ID=3340. Retrieved March 10, 2016.

32. Wallbaum, H, and Buerkin, C. (2003). Concepts and Instruments for a Sustainable construction sector. Industry and Environment: Sustainable Buildings and Construction United Nations Environment Programme, 26 (2-3): 53-57.

33. Wilson, A. Making the Case for Green Building. Environmental Building News (April 2005):2,12

34. Woolley, T. (Ed). (2000). Green Building: Establishing Principles. Ethics and the Built Environment (pp. 44-56).Warwick Fox. Rutledge, London.

35. Whole Building Design Guide (2014) Sustainable Building Committee; International Journal of sustainable building Technology and Urban Development, 4(2), 15-21

36. Wuni Y. Ibrahim, Geoffrey Q. P. Shen \& Abba Tahir Mahmud (2019) Critical risk factors in the application of modular integrated construction: a systematic review, International Journal of Construction Management, $\quad$ DOI: $\underline{10.1080 / 15623599.2019 .1613212}$

37. Wyatt, D. P. (1994). Recycling and Serviceability: The Twin Approach to Securing Sustainable construction: Proceedings of First International Conference of CIB TG 16 on Sustainable Construction, Tampa, Florida, USA, 6-9 November, pp. 69-78.

38. Yong Han Ahn, Annie, R., Pearce, Yuhong Wang, \& George Wang. (2014). Drivers and barriers to sustainable design and construction: The perception of green building experience. International Journal 
Moderating Impact of Sustainable Building Awareness on the Relationship between Sustainability Concepts Application, Sustainability Constraints, and Knowledge Level

of SustainableBuilding Technology and Urban Development, 4(1), 35-45. http://dx.doi.org/10.1080/2093761X.2012.759887

39. Zubairu, S. (2012) The Importance of Evaluation and Sustainability in the built environment In: Laryea, S., Agyeponng, S., Leininger, R. and Hughes, W. (Eds) Procs 4th West Africa Built Environment Research (WABER) Conference, 24-26 July Abuja, Nigeria, 9-13.

40. Zainul Abidin, N. (2005) "Using Value Management to Improve the Consideration of Sustainability within Construction",Ph.D. Thesis, Loughborough University, United Kingdom, 